ORIGINAL ARTICLE

\title{
Biological control of grey mould in strawberry fruits by halophilic bacteria
}

\author{
B. Essghaier ${ }^{1}$, M.L. Fardeau ${ }^{2}$, J.L. Cayol ${ }^{2}$, M.R. Hajlaoui ${ }^{3}$, A. Boudabous ${ }^{1}$, H. Jijakli ${ }^{4}$ \\ and N. Sadfi-Zouaoui ${ }^{1}$ \\ 1 Laboratoire Microorganismes et Biomolécules Actives, Faculté des Sciences de Tunis, Campus universitaire, Tunisia \\ 2 Institut de Recherche pour le Développement (IRD), Université de Provence et de la Méditerranée Marseille, France \\ 3 Laboratoire de Protection des Végétaux, Institut National de la Recherche Agronomique de Tunisie (INRAT), Ariana, Tunisia \\ 4 Unité de Phytopathologie, Faculté Universitaire des Sciences Agronomiques de Gembloux, (fsagx) Belgium
}

\section{Keywords}

antifungal enzymes, biocontrol, Botrytis cinerea, grey mould, halophilic bacteria, postharvest disease, strawberries.

\section{Correspondence}

Najla Sadfi-Zouaoui, Laboratoire

Microorganismes et Biomolécules Actives, Faculté des Sciences de Tunis, Campus universitaire, 2092 Tunisia.

E-mail: sadfi.najla@planet.tn

2008/0241: received 12 February 2008, revised 26 August 2008 and accepted 29 August 2008

doi:10.1111/j.1365-2672.2008.04053.x

\begin{abstract}
Aims: Grey mould caused by Botrytis cinerea is an economically important disease of strawberries in Tunisia and worldwide. The aim of this study was to select effective halophilic bacteria from hypersaline ecosystems and evaluate the abilities of antifungal bacteria to secrete extracellular hydrolytic enzymes, antiBotrytis metabolites and volatiles.

Methods and Results: Grey mould was reduced in strawberry fruits treated with halophilic antagonists and artificially inoculated with $B$. cinerea. Thirty strains $(20 \cdot 2 \%)$ were active against the pathogen and reduced the percentage of fruits infected after 3 days of storage at $20^{\circ} \mathrm{C}$, from $50 \%$ to $91 \cdot 66 \%$. The antagonists were characterized by phenotypic tests and $16 \mathrm{~S}$ rDNA sequencing. They were identified as belonging to one of the species: Virgibacillus marismortui, B. subtilis, B. pumilus, B. licheniformis, Terribacillus halophilus, Halomonas elongata, Planococcus rifietoensis, Staphylococcus equorum and Staphylococcus sp. The effective isolates were tested for antifungal secondary metabolites.

Conclusions: Moderately halophilic bacteria may be useful in biological control against this pathogen during postharvest storage of strawberries.

Significance and Impact of the study: The use of such bacteria may constitute an important alternative to synthetic fungicides. These moderate halophiles can be exploited in commercial production and application of the effective strains under storage and greenhouse conditions.
\end{abstract}

\section{Introduction}

Strawberry is an important small fruit crop grown worldwide, and its production is increasing steadily. Among major factors limiting strawberry yield are susceptibility to a variety of phytopathogenic fungi, bacteria and viruses (Schestibratov and Dolgov 2005). Grey mould caused by Botrytis cinerea pers: Fris is one of the most destructive diseases of strawberry in Tunisia and worldwide and can cause yield losses of up to $25 \%$ for untreated strawberries. In strawberry, the fungus attacks flowers, setting fruits, mature fruits and leaves (Sutton 1990; Sutton and Peng 1993). Grey mould is also a major cause of postharvest losses during storage, transit and shipment. The postharvest life of the strawberry (Fragaria ananassa Duch) is largely limited by $B$. cinerea infection. It is assumed that there are two factors influencing the batch keeping quality: the Botrytis inoculum potential and the resistance of the strawberry to infection (Schouten et al. 2002).

The most important method of control of $B$. cinerea on strawberries is the application of fungicides during flowering. But fungicides are generally not effective unless they are timed properly and used in conjunction with the cultural practices. However some of the more effective fungicides have not been registered for use in strawberry and others have developed resistance problems (Paulus 1990). Therefore, the reduction of synthetic fungicide applications and elaboration of safe and effective alternative approaches for the control of postharvest disease are necessary (Wilson and Wisniewski 1989). 
The search of antagonists for plant protection has intensified in the recent years and several micro-organisms with high activity have been identified. Several biological control agents are effective in reducing decay caused by grey mould on strawberry (Lim et al. 1991; Peng and Sutton 1991). However, few of these have been tested under postharvest storage conditions (Burmeister et al. 1997; Wszelaki and Mitcham 2000). The use of microbial antagonists is one of the most studied alternatives to fungicides that has lead to the development and release of commercial products such as Candida oleophila (Saligkarias et al. 2002), Cryptococcus albidus (Ippolito et al. 2005), Pseudomonas syringae (Bull et al. 1997) and Bacillus subtilis (El-Ghaouth et al. 1998; Utkhede et al. 2001).

Our previous laboratory studies showed the efficiency of halotolerant Bacillus isolates in the control of potato dry rot under storage conditions (Sadfi et al. 2001, 2002). We also described the ability of halotolerant and moderately halophilic bacteria isolated from different Tunisian Sebkhas (hypersaline soils) to protect fresh-market tomato fruits from B. cinerea (Sadfi-Zouaoui et al. 2008). These halophilic micro-organisms produce antibiotics and antifungal metabolites and are able to control phytopathogenic fungi. However, the halotolerant and moderately halophilic bacteria have not been tested yet against grey mould on harvested strawberries.

Moderately halophilic bacteria are a group of halophilic micro-organisms able to grow optimally in media containing a wide range of $\mathrm{NaCl}$ concentrations (3-15\% $\mathrm{NaCl}$ ) (Ventosa et al. 1998). They constitute a heterogeneous group of micro-organisms and have been studied for their ecology, physiology, biochemistry and genetics (Ventosa et al. 1998). However their biotechnological possibilities have not been extensively exploited. Furthermore, halophiles are the most likely source of extracellular hydrolytic enzymes such as amylases, proteases, lipases, DNAses, pullulanases, phosphatases, xylanases and nucleases which have different potential usages in biotechnological and industrial processes such as food industry, feed additive, biomedical sciences and chemical industries (Niehaus et al. 1999). Moreover, extremophilic micro-organisms are adapted to survive in ecological niches such as at high temperature, extremes of $\mathrm{pH}$, high salt concentrations and high pressure. These micro-organisms produce unique biocatalysts that function under extreme conditions comparable to those prevailing in various industrial processes (Niehaus et al. 1999). The production of hydrolytic enzymes which degrade fungal cell walls, especially chitinases and $\beta$-1,3-glucanases, are among key factors involved in the suppression of pathogenic fungi by biocontrol agents (Ordentlich et al. 1988).

The objective of our study was to evaluate, under postharvest conditions the effectiveness of halophilic bacteria in reducing strawberry rot caused by Botrytis cinerea under storage conditions. The ability of halophilic antagonists to produce diversity of extracellular hydrolytic enzymes, including antifungal ones as well as other antifungal compounds was also investigated.

\section{Materials and methods}

\section{Pathogen inoculum}

A monosporal isolate of B. cinerea (LPV 02) used for laboratory trials has been isolated from infected strawberry fruits with typical symptoms of grey mould rot. The fungal pathogen was cultivated on plates of potato dextrose agar (PDA, Difco) for 10 days at $25^{\circ} \mathrm{C}$ until sporulation. A monosporal isolate was maintained on PDA at $+4^{\circ} \mathrm{C}$ and was subcultured onto fresh PDA plates every 2 month-intervals.

A spore suspension was prepared by flooding 10day-old cultures of $B$. cinerea on PDA dishes with $15 \mathrm{ml}$ of sterile distilled water supplemented with $0.01 \%$ Tween $80(\mathrm{w} / \mathrm{v})$ and dislodging the spores with a glass rod. The suspension was filtered through a sterile $30 \mu \mathrm{m}$ filter to discard conidiophores and fragments of mycelium. Conidial suspension of $B$. cinerea was adjusted to $10^{6}$ spores $\mathrm{ml}^{-1}$ by counting with a haemocytometer.

\section{Fruits}

Mature and healthy strawberries were uniform in size and colour, free from wounds and rot. Before each test, the fruits were washed with a sodium hypochlorite solution ( $1 \%$ active chlorine), then rinsed in distilled water and left to dry by using sterile filter papers.

\section{Antagonistic bacteria}

In a recent study a total of 148 halotolerant to halophilic bacteria were isolated during 2004-2005 from four shallow salt lakes, or Sebkhas, located in different areas of Tunisia (Sadfi-Zouaoui et al. 2008). Strains were maintained on Tryptic Soy Agar (TSA, Difco) slants with $7 \cdot 5 \%, 10 \%$ or $20 \% \mathrm{NaCl}(\mathrm{w} / \mathrm{v})$ at $4^{\circ} \mathrm{C}$ and subcultured every 2-month intervals. For long-term storage, strains were conserved in $75 \%$ glycerol at $-80^{\circ} \mathrm{C}$.

To evaluate their antagonistic activity against $B$. cinerea on strawberry fruits, all halophilic bacterial strains were incubated on TSA medium supplemented with $7 \cdot 5 \%$, $10 \%$ or $20 \% \mathrm{NaCl}$ at $30^{\circ} \mathrm{C}$ for $48 \mathrm{~h}$. After $48 \mathrm{~h}$, the cells were scraped from the agar and diluted in sterilized saline solution $(0 \cdot 1 \% \mathrm{NaCl})$. Bacterial suspensions were adjusted to $10^{8}$ colony-forming units (CFU) $\mathrm{ml}^{-1}$. Bacterial concentration was determined by dilution plating on TSA. 
In vivo screening of halophilic isolates for anti-Botrytis activity

Harvested strawberries were soaked in a bacterial suspension $\left(10^{8} \mathrm{CFU} \mathrm{ml} \mathrm{m}^{-1}\right)$ for $12 \mathrm{~s}$, dried for $1 \mathrm{~h}$ and sprayed with a conidial suspension of $B$. cinerea at $10^{6}$ spores $\mathrm{ml}^{-1}$ and then placed in plastic tray containers. As positive and negative controls, fruits were either inoculated with the pathogen alone, with the bacterial candidate alone or with distilled water. The fruits were then stored according to Tunisian commercial standard at $20^{\circ} \mathrm{C}$, and $95 \% \mathrm{RH}$ during 3-4 days.

The percentage of disease incidence of grey mould on the strawberry fruits was calculated using the following formula: $(\%)=(A / B) \times 100$, where $A$ is the number of infected strawberry fruits in a bacterial treated tray and $B$ is the number of total fruits per tray. Three independent experiments were performed with 20 fruits per treatment (strain) and each experiment was used as a repetition for the statistical analysis using LSD test. Only the isolates showing disease incidence of less than $50 \%$ on strawberry fruits were retained for further identification and analysis.

\section{In vitro screening of halophilic antagonists}

The efficiency of halotolerant to moderately halophilic isolates inhibited the growth of $B$. cinerea on strawberry fruits was also verified in vitro by applying a dual culture technique (Sadfi-Zouaoui et al. 2008). Two mycelial plugs of $5 \mathrm{~mm}$ in diameter of $B$. cinerea were placed at each side of the bacterial strip. The distance between the two micro-organisms was $2.5 \mathrm{~cm}$. Plates were then incubated at $25^{\circ} \mathrm{C}$ for 5 days. The percentage of mycelial growth inhibition was calculated by the formula: Growth inhibition $(\mathrm{GI})=\left(R_{1}-R_{2}\right) / R_{1} \times 100$, where $R_{1}$ represents the distance (measured in millimeter) between the point of implant of the fungal disc and the side of the Petri plate, and $R_{2}$ is the distance of fungal growth from the point of inoculation to the colony margin in the direction of the antagonist (Sadfi-Zouaoui et al. 2008). All in vitro antagonism assays were made in triplicate.

\section{Statistical analysis}

Data were analysed according to a factorial design with one factor. Analysis of variance of data collected from the percentage of disease incidence of different bacterial treatments including the control (NTC) and the percentage of growth inhibition of $B$. cinerea on PDA plates and means comparisons by LSD method at the level of $5 \%$, were carried out using statistica program ver. 5.0 (StatSoft France, 1997).

\section{Identification of halophilic bacteria}

\section{Phenotypic characterization}

The effective biocontrol isolates were phenotypically characterized on the basis of morphological, physiological and chemical analyses. Active strains were identified according to the methods of Grant et al. (2001) and Hacene et al. (2003), which are based on the following phenotypic features: colony and cell morphology, motility, spore production when present, Gram staining, pigmentation and growth at optimal $\mathrm{pH}$, temperature and salinity. The susceptibility to antimicrobial agents was tested on TSA medium containing $75 \mathrm{~g} \mathrm{l}^{-1} \mathrm{NaCl}$ with antibiotic discs (Difco), by the method of Tindall (1992). The antibiotics tested were: penicillin $\mathrm{G}$ (10 units), erythromycin $(15 \mu \mathrm{g})$, bacitracin (10 units), chloramphenicol (30 $\mu \mathrm{g})$, neomycin $(30 \mu \mathrm{g})$, ampicillin $(10 \mu \mathrm{g})$ and rifampicin $(30 \mu \mathrm{g})$. Oxidase reaction was performed by impregnating discs with dimethyl- $P$-phenylenediamine (Biomérieux, France). Catalase was determined by adding 10 volumes of $\mathrm{H}_{2} \mathrm{O}_{2}$ to each strain culture $(18 \mathrm{~h})$ on solid TSA medium. Acid production from carbohydrates (D-glucose, sucrose, lactose) was detected on liquid TSB medium supplemented with $7 \cdot 5 \%$ $\mathrm{NaCl}(\mathrm{w} / \mathrm{v}) . \mathrm{H}_{2} \mathrm{~S}$ production was performed according to Clarke (1953). Nitrate reduction was assayed by adding $0 \cdot 2 \%(\mathrm{w} / \mathrm{v}) \mathrm{KNO}_{3}$ to the liquid TSB medium. Nitrite was detected as described by Skerman (1967). Urea hydrolysis was detected with Christensen's medium (1946). $\beta$-galactosidase and Voges-Proskauer tests were performed by standard procedures (Barritt 1936; Lowe 1962).

\section{$16 \mathrm{~S}$ rRNA gene sequence determination}

\section{Chromosomal DNA preparation}

The cells were harvested at approximately the late exponential growth phase by centrifugation and resuspended in TE (10 mmol $\mathrm{l}^{-1}$ Tris-HCl, $1 \mathrm{mmol} \mathrm{l}^{-1}$ EDTA pH 8). Cells of Gram-positive bacteria were lysed by adding respectively for $30 \mathrm{~min}$ at $37^{\circ} \mathrm{C}$; lysozyme $\left(30 \mathrm{mg} \mathrm{ml}^{-1}\right)$; proteinase $\mathrm{K}$ $\left(20 \mathrm{mg} \mathrm{ml}^{-1}\right)$ and SDS $10 \%$. Chromosomal DNA was extracted by using the 'Wizard Genomic DNA purification kit' (Promega), according to the manufacturer's protocol. The DNA preparations were visually inspected by $0 \cdot 8 \%$ $(\mathrm{w} / \mathrm{v})$ agarose gel electrophoresis, and stored at $-20^{\circ} \mathrm{C}$.

\section{PCR amplification}

The 16S rRNA gene of the isolate was amplified by adding $0 \cdot 5 \mu$ l DNA extract to a thermocycler microtube containing

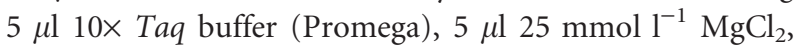
$0.5 \mu \mathrm{l} 100 \mathrm{nmol} \mathrm{l}^{-1}$ primers, $37 \cdot 7 \mu \mathrm{l}$ sterile distilled water and $0.3 \mu \mathrm{l} 5 \mathrm{U}$ Taq polymerase $\mu \mathrm{l}^{-1}$ (Promega). The universal primers Fd1 (5'-AGAGTTTGATCCTGGCTCAG-3', positions 8-28) and Rd1 (5'-AAGGAGGTGATCCAGCC-3', 
positions 1547-1531, MWG) (Escherichia coli numbering), were used to obtain the PCR product (Winker and Woese 1991). The PCR profile was consisting of initial denaturation at $96^{\circ} \mathrm{C}$ for $3 \mathrm{~min}$ followed by 30 cycles of annealing at $57^{\circ} \mathrm{C}$ for $30 \mathrm{~s}$, extension at $72^{\circ} \mathrm{C}$ for $2 \mathrm{~min}$ and denaturation at $96^{\circ} \mathrm{C}$ for $30 \mathrm{~s}$ and finally, an extension cycle of $72^{\circ} \mathrm{C}$ for $7 \mathrm{~min}$.

16SrDNA gene sequencing and phylogenetic analysis PCR products were purified with a QIAquick gel extraction Kit. Direct sequencing of the PCR product was performed by Genome Express (Grenoble, France). The rRNA gene sequences of the strains have been aligned with related bacteria sequences obtained from Genbank (Benson et al. 1999), using the SEQUence ALIGNer software from the Ribosomal Database Project II (Maidak et al. 2001) and the sequence alignment editor BioEdit (Hall 1999) as previously detailed by Sadfi-Zouaoui et al. 2008. All the phylogenetic programs are implemented in the Treecon package (Van de Peer and De Wachter 1994).

\section{Detection of antibiotic activity}

The selected isolates exhibiting antifungal activity against B. cinerea were grown on TSB medium with $7 \cdot 5 \%, 10 \%$ or $20 \% \mathrm{NaCl}(\mathrm{w} / \mathrm{v})$ at $30^{\circ} \mathrm{C}$ for $24 \mathrm{~h}$. The bacterial suspension was centrifuged at $10000 \mathrm{~g}$ for $10 \mathrm{~min}$ at $4^{\circ} \mathrm{C}$.

Antibiotic assays were performed on 9-cm Petri plates containing $20 \mathrm{ml}$ of PDA medium. A fungal plug $(5 \mathrm{~mm})$ cut from the outer edges of a 5-day old culture of B. cinerea was placed in the centre of the Petri plate. A well (diameter, $10 \mathrm{~mm}$ ) was made at $2 \mathrm{~cm}$ from the fungal plug using a No. 3 sterile cork borer and filled with $100-\mu \mathrm{l}$ of the crude antibiotic extract that has been passed through a $0 \cdot 2-\mu \mathrm{m}$ Acrodisc syringe filter (Pall Corp., East Hills, USA). For the crude antibiotics extracted from liquid cultures, a control consisted of filter-sterilized distilled water. Plates were kept at $5^{\circ} \mathrm{C}$ for $2 \mathrm{~h}$ to allow for diffusion of the sample, then were inverted and incubated at $25^{\circ} \mathrm{C}$ for 5 days. The results were reported as a percentage of fungal growth reduction. Three plates with one measurement per plate were used for each sample and the experiment was repeated twice.

\section{Detection of antifungal activity of volatiles}

The production of volatile compounds by selected halophilic strains (i.e. B. subtilis J9; Terribacillus halophilus J31; B. pumilus M3-16; B. marismortui M3-23; Halomonas elongata L80; Planococcus rifietoensis M2-26) was assayed by a sealed plate method as described by Fiddman and Rossall (1995). From a 24-h TSB culture of halophilic isolate, $200 \mu \mathrm{l}$ were spread on TSA medium in a Petri dish. After incubation at $30^{\circ} \mathrm{C}$ for $24 \mathrm{~h}$, a second Petri dish (containing PDA), was inoculated with a 6-mm plug of the test fungus in the centre of the plate, inverted and placed over the bacterial culture. The two plates were sealed together with a parafilm and further incubated at $25^{\circ} \mathrm{C}$. This ensured that both organisms were growing in the same atmosphere with being physically separated. As a control, a Petri dish containing TSA medium without bacteria was placed over the PDA medium inoculated with the fungal pathogen. Fungal growth was measured by following the increase in radial spread of the test fungus for a period of 5 days. Each test was replicated three times.

\section{Detection of extracellular hydrolytic enzymes}

\section{Chitinase activity}

The selected halotolerant and halophilic isolates with antifungal activity against $B$. cinerea were cultured in a medium containing (per litre) $\left(\mathrm{NH}_{4}\right)_{2} \mathrm{SO}_{4}, 7 \mathrm{~g} ; \mathrm{K}_{2} \mathrm{HPO}_{4}$, $1 \mathrm{~g} ; \mathrm{NaCl}, 1 \mathrm{~g}, \mathrm{MgSO}_{4} .7 \mathrm{H}_{2} \mathrm{O}, 0.1 \mathrm{~g}$; yeast extract, $0.5 \mathrm{~g}$; agar, $15.0 \mathrm{~g}$. The medium was supplemented with $7 \cdot 5$, 10.0 or $15.0 \% \mathrm{NaCl}(\mathrm{w} / \mathrm{v})$ and $0.5 \%$ colloidal chitin prepared according to Rodriguez-Kabana et al. (1983). Bacteria showing clearing zones after 7 days of incubation at $30^{\circ} \mathrm{C}$ on colloidal chitin agar were considered as chitinase producers.

\section{Glucanase activity}

Halophilic strains were cultured at $30^{\circ} \mathrm{C}$ for 3 days on a rotary shaker in $15 \mathrm{ml}$ tubes containing $6 \mathrm{ml}$ peptone medium containing laminarin $(0 \cdot 1 \%)$ (from Laminarin digitata; Sigma) (Lim et al. 1991) plus 7.5\%, 10\%, 15\% or $20 \% \mathrm{NaCl}(\mathrm{w} / \mathrm{v})$. The cultures were then centrifuged at $12000 \mathrm{~g}$ for $20 \mathrm{~min}$ at $4^{\circ} \mathrm{C}$ and the supernatant was used as enzyme solution. The standard assay was performed according to the method of Leelasuphakul et al. (2006). The amount of reducing sugar from Laminarin was measured. The standard assay contained $10 \mu \mathrm{l}$ of the enzyme solution and $90 \mu \mathrm{l}$ of $5 \mathrm{mg} \mathrm{ml}^{-1}$ of laminarin in $0 \cdot 1 \mathrm{~mol} \mathrm{l}^{-1}$ sodium acetate buffer $\mathrm{pH} 5 \cdot 0$. After incubation at $40^{\circ} \mathrm{C}$ with gentle shaking for $10 \mathrm{~min}$, the reaction was stopped by boiling for $5 \mathrm{~min}$ and $0.2 \mathrm{ml}$ of $1 \%$ dinitrosalicylate (DNS) and $0.2 \mathrm{ml}$ of sodium acetate buffer were added and boiled for another $5 \mathrm{~min}$, then placed in an ice bath and $0.9 \mathrm{ml}$ distilled $\mathrm{H}_{2} \mathrm{O}$ was added. The optical absorbance was measured at $540 \mathrm{~nm}$. The amount of reducing sugars released was calculated from a standard curve prepared with glucose and the glucanase activity was expressed in units ( $\mu$ mole glucose equivalent $\min ^{-1}$ ).

\section{Protease activity}

Proteolytic activity was assayed by measuring zones of precipitation of paracasein around bacterial colonies 
grown for $48 \mathrm{~h}$ at $30^{\circ} \mathrm{C}$ in agarized saline medium supplemented with 50\% (w/v) milk, 10\% (w/v) $\mathrm{NaCl}$ and $0 \cdot 5 \%(\mathrm{w} / \mathrm{v})$ yeast extract (Difco).

\section{Cellulase activity}

Cellulolytic activity of isolates was detected by screening for zones of hydrolysis around the colonies growing on TSA medium supplemented with $1 \%$ cellulose. After incubation at $30^{\circ} \mathrm{C}$ for approx. 7 days, the plates were flooded respectively with Congo-red $\left(1 \mathrm{mg} \mathrm{m}^{-1}\right)$ for $15 \mathrm{~min}$ and $\mathrm{NaCl} 1 \mathrm{~mol} \mathrm{l}^{-1}$ for $15 \mathrm{~min}$. Cellulolytic activity was taken as evidence by appearance of clear zone around the colonies.

\section{Chitinase quantification and induction}

Bacterial cultures were grown in M1 or M4 media prepared by supplementing the Difco tryptone glucose yeast medium with $7 \cdot 5 \%$ or $10 \%(\mathrm{w} / \mathrm{v}) \mathrm{NaCl}$ and with either $1 \mathrm{~g} \mathrm{l}^{-1}$ glucose (M1) or $1 \mathrm{~g} \mathrm{l}^{-1}$ glucose plus $0 \cdot 3 \%(\mathrm{w} / \mathrm{v})$ colloidal chitin (M4). For the induction test by the presence of the pathogen; the autoclaved spores of $B$. cinerea $\left(10^{6}\right.$ spores $\mathrm{ml}^{-1}$ ) were added to the TGY medium containing $0 \cdot 1$ or $1 \mathrm{~g} \mathrm{l}^{-1}$ of glucose respectively in media M3 and M2. After
3 days of incubation at $30^{\circ} \mathrm{C}, 180 \mathrm{rev} \mathrm{min}^{-1}$, the cell-free supernatant (enzyme sample) was used for the enzyme assay. The chitinase activity was determined according to the method of Gomez Ramirez et al. (2003). Enzyme samples (one millilitre) were added to $1 \mathrm{ml}$ of colloidal chitin suspension $(10 \%)$ in $0 \cdot 2 \mathrm{~mol} \mathrm{l}^{-1}$ sodium phosphate buffer $(\mathrm{pH} 7 \cdot 0)$. The mixture was incubated for $1 \mathrm{~h}$ at $50^{\circ} \mathrm{C}$. The reaction was terminated by adding $1 \mathrm{ml}$ of $1 \% \mathrm{NaOH}$ followed by boiling for $5 \mathrm{~min}$ and the absorption was measured at $535 \mathrm{~nm}$. The product was determined by 3, 5 dinitrosalicylic acid assay (DNS) as detailed by the study of Gomez Ramirez et al. (2003). A calibration curve was plotted using $N$-acetylglucosamine (NAG; Sigma). In this case, the chitinase activity was defined as the amount of enzyme required to produce one $\mu \mathrm{mol}$ of NAG per hour (Roja Avelizapa et al. 1999).

\section{Results}

Screening of effective antagonists in vivo

Results presented in Fig. 1 indicate that 30 out of 148 tested isolates (c. 20.2\%) significantly reduced the strawberry grey mould rot incidence comparing with the nontreated
Figure 1 Effect of the most active halotolerant (a) and halophilic (b) bacterial isolates on the disease incidence on strawberries. Strawberries were soaked in a bacterial suspension, dried and sprayed with a conidial suspension of Botrytis cinerea. After 3-4 days of storage at $20^{\circ} \mathrm{C}$, the number of infected fruits were recorded in both treated and control trays. Twenty fruits per treatment were used and data were recorded from three experiments. Note: bars with the same letter did not differ significantly at $P=0.05$ by LSD test. NTC: nontreated controls (fruits inoculated with Botrytis).
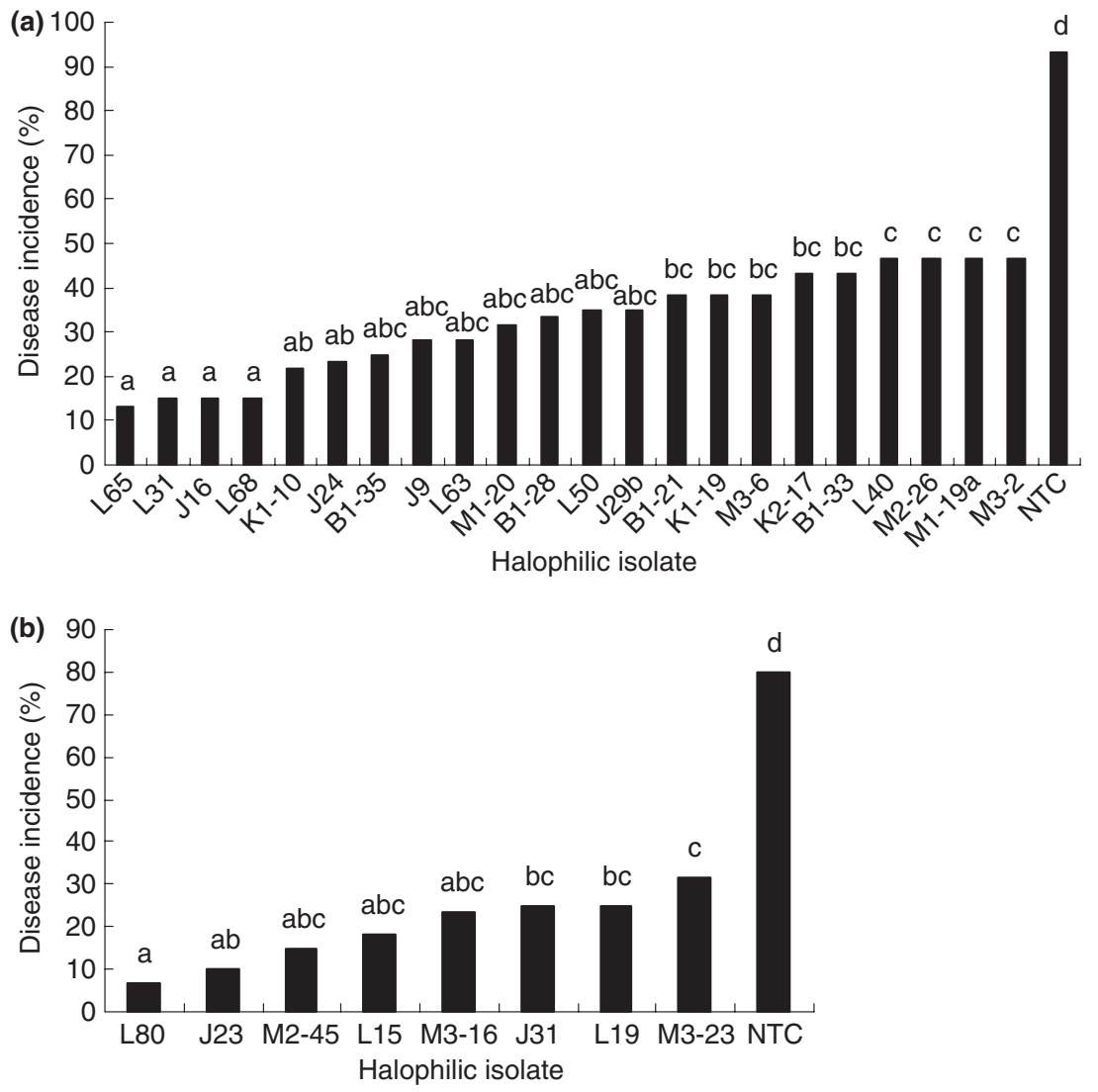
control (NTC). The halotolerant to moderately halophilic strains isolated in a medium containing $7 \cdot 5-10 \%(\mathrm{w} / \mathrm{v})$ $\mathrm{NaCl}$ gave a percentage of grey mould reduction ranging from $50 \%$ to $85 \cdot 71 \%$ (Fig. 1a). The most effective strains were L65, L31, J16 and L68 which can reduce grey mould disease on strawberries from $83 \cdot 93 \%$ to $85 \cdot 71 \%$. The highest reduction was obtained with two moderately halophilic isolates of J23 and L80 which almost completely inhibited the growth of the pathogen and resulted in percentage grey mould reduction by respectively $87.5 \%$ and $91.66 \%$ (Fig. 1b). The latter strains were isolated in a medium containing 20\% $\mathrm{NaCl}(\mathrm{w} / \mathrm{v})$.

\section{Identification of selected antagonists}

The phenotypic characterization was carried out with the 30 effective strains (Table 1). This preliminary identification revealed that $33.4 \%$ of the biocontrol isolates belonged to the genus Bacillus and $40 \%$ to Staphylococcus. Isolate L80 was identified as a member of the genus Halomonas. Isolates B1-21, K1-19 and M3-23 were identified as belonging to the genus Virgibacillus, while J16, L15 and J31 belonged to Terribacillus genera.

From the 16S rDNA sequence analysis (Fig. 2), the most halotolerant to moderately halophilic active isolates were identified as belonging to Virgibacillus marismortui (B1-21), Terribacillus halophilus (J31), Bacillus subtilis (B1-33), B. pumilus (M3-16, L65, K1-10), Halomonas elongata (L80), Staphylococcus equorum and Staphylococcus spp. The 16S rDNA sequences of these isolates have been deposited in the GenBank database, under the accession numbers EU435360 for B1-21, EU435359 for J31, EU435361 for B133, EU435356 for M3-16, EU435357 for L65 and EU435355 for L80. B. licheniformis J24 (accession no EF471917), B. subtilis J9, M1-20 (accession no EF471915, EF471916), and Planococcus rifietoensis M2-26 (accession no EF471920) previously selected on tomato fruits (Sadfi-Zouaoui et al. 2008) were among the active isolates on strawberries.

\section{Screening of effective antagonists in vitro}

The results of the in vitro dual culture assay showed that 21 isolates $(70 \%)$, previously selected, reduced the mycelial growth of $B$. cinerea. Although very effective in vivo on strawberries, nine isolates were unable to inhibit B. cinerea on solid medium. Among 21 active isolates, 16 gave a percentage inhibition growth ranging from $81 \%$ to 99.5\% (Table 1). All the active halotolerant bacteria in vitro, growing at salt concentration ranging from $5 \%$ to $10 \%$ belonged to B. licheniformis (J24) and B. subtilis (M1-20, B1-33) species, while only the halotolerant strain of B. subtilis J9 failed to inhibit the pathogen (Table 2). Furthermore, the selected moderately halophilic bacteria growing over a broad range of $\mathrm{NaCl}(5-15 \% ; 5-20 \%)$ effectively inhibited mycelial development of $B$. cinerea. The best inhibitory activity was obtained by the strain L80 of Halomonas elongata. However, Virgibacillus marismortui strains, Terribacillus halophilus strains, Staphylococcus equorum (B1-35) and Staphylococcus sp. (J23) were ineffective in vitro.

\section{Detection of antibiotic activity}

The bacterial cell-free extracts of the species B. licheniformis (J24) and B. pumilus (M3-16) were bioactive against $B$. cinerea as inhibition zones were detected around the wells. These antifungal substances resulted respectively in $41.96 \%$ and $42.15 \%$ reduction in fungal growth after 5 days of incubation. The cell-free filtrates of all other active isolates were unable to inhibit the growth of B. cinerea in vitro.

\section{Detection of antifungal activity of volatiles}

The results of experiments of the effect of halophilic isolates volatiles on the growth of the pathogen are presented in Table 3. These experiments showed variable fungal growth according to the tested bacterial antagonist compared to the control. On PDA, six halophilic isolates out of seven showed inhibitory effect on Botrytis growth (Table 3).

The highest volatile activities were obtained by the strains, M3-16 of B. pumilus, M3-23 of B. marismortui and L80 of $H$. elongata which seem to be effective in producing volatiles against the pathogen. These isolates resulted in more than $49.4 \%$ reduction in fungal growth after $120 \mathrm{~h}$ of incubation.

\section{Extracellular hydrolytic activities}

All B. cinerea-inhibiting halophilic strains produced chitinase and $\beta$-1,3-glucanase except $H$. elongata L80, which did not form clearing zones on colloidal chitin agar (Table 4). On average, Bacillus spp. produced higher amounts of antifungal enzymes when compared to other halophilic bacterial species. Four tested isolates (T. halophilus J31, T. halophilus J16, B. subtilis B1-33, and B. pumilus M3-16) produced protease, and only three isolates (B. subtilis B1-33, B. pumilus M3-16, and B. pumilus M3-2) tested positive for cellulase activity.

\section{Chitinase quantification and induction}

The production of chitinase by halophilic antagonists was significantly influenced by the carbon source incorporated into the medium and the presence or 
Table 1 Phenotypic characterization of active isolates

\begin{tabular}{|c|c|c|c|c|c|c|c|c|c|}
\hline \multirow{2}{*}{$\frac{\text { Characteristics }}{\text { Colonial morphology }}$} & \multirow{2}{*}{$\frac{\text { B1-28 }}{\text { Circular }}$} & B1-33 & B1-35 & M2-45 & M3-2 & \multirow{2}{*}{$\frac{\text { M3-6 }}{\text { Circular }}$} & \multirow{2}{*}{$\frac{\text { M3-16 }}{\text { Circular }}$} & \multirow{2}{*}{$\begin{array}{l}\text { M3-23 } \\
\text { Irregular }\end{array}$} & \multirow{2}{*}{$\frac{\text { B1-21 }}{\text { Circular }}$} \\
\hline & & Circular & Circular & Circular & Circular & & & & \\
\hline Cell shape & Coccoid & Rod & Coccoid & Coccoic & Rod & Rod & Rod & Rod & Rod \\
\hline Spore production & + & + & + & + & + & + & + & + & + \\
\hline Motility & + & + & + & + & + & + & + & + & + \\
\hline Pigmentation & Cream & Cream & Cream & Cream & Cream & Cream & Cream & Cream & Cream \\
\hline Anaerobic growth & - & - & - & - & - & - & - & - & - \\
\hline Gram stain & + & + & + & + & + & + & + & + & + \\
\hline Optimal $\mathrm{NaCl}$ for growth (\%) & 10 & $7 \cdot 5$ & 10 & 10 & $7 \cdot 5$ & $7 \cdot 5$ & 10 & 10 & 10 \\
\hline Optimal temperature for growth $\left({ }^{\circ} \mathrm{C}\right)$ & 37 & 30 & 37 & 30 & 30 & 30 & 30 & 30 & 30 \\
\hline Optimal pH for growth & $6-7$ & $7 \cdot 5$ & $6-7$ & $6-7$ & 7 & 7 & 7 & 6 & 8 \\
\hline \multicolumn{10}{|l|}{ Sensitivity to antibiotics } \\
\hline Erythromycin & $\mathrm{R}$ & $S$ & $\mathrm{R}$ & $R$ & $\mathrm{R}$ & S & $\mathrm{R}$ & $S$ & S \\
\hline Bacitracin & S & S & S & S & S & $S$ & $\mathrm{R}$ & $\mathrm{R}$ & $\mathrm{R}$ \\
\hline Neomycin & $\mathrm{R}$ & $\mathrm{R}$ & S & $\mathrm{R}$ & S & R & $\mathrm{R}$ & $\mathrm{S}$ & R \\
\hline Chloramphenicol & S & S & S & S & S & S & $S$ & $S$ & S \\
\hline Ampicillin & S & S & $S$ & $R$ & S & S & $\mathrm{R}$ & $\mathrm{R}$ & S \\
\hline Penicillin & S & S & S & R & S & $\mathrm{R}$ & $\mathrm{R}$ & $\mathrm{R}$ & R \\
\hline Rifampicin & $S$ & S & S & S & S & S & $S$ & $S$ & $S$ \\
\hline Catalase & + & + & + & + & + & + & + & + & + \\
\hline Oxidase & - & - & - & - & - & + & + & + & + \\
\hline $\mathrm{H}_{2} \mathrm{~S}$ production & - & - & - & + & - & - & - & - & - \\
\hline Nitrate reduction & + & ++ & + & + & ++ & ++ & ++ & + & + \\
\hline Vogues-Proskauer test & - & - & - & - & + & + & + & - & - \\
\hline Gas formation & - & - & - & + & + & + & + & + & - \\
\hline \multicolumn{10}{|l|}{ Acid production from } \\
\hline Sucrose & - & - & - & - & - & - & - & - & - \\
\hline Lactose & - & - & - & - & - & + & + & - & - \\
\hline D-Glucose & - & - & - & - & - & + & + & - & - \\
\hline \multicolumn{10}{|l|}{ Hydrolysis of } \\
\hline Esculin & - & + & + & + & + & + & + & + & + \\
\hline Starch & - & + & - & - & - & + & + & - & - \\
\hline Casein & - & + & - & - & - & - & + & - & - \\
\hline Gelatin & - & - & + & + & + & - & + & + & + \\
\hline Tween80 & - & - & - & - & - & - & + & - & - \\
\hline Urease & + & - & - & - & + & - & + & + & - \\
\hline$\beta$-galactosidase & + & + & + & + & + & + & + & + & + \\
\hline Characteristics & L65 & L80 & L63 & & L68 & $J 23$ & J31 & J16 & $J 29 b$ \\
\hline Colonial morphology & Circular & Circular & Circular & & Circular & Circular & Circular & Circular & Circular \\
\hline Cell shape & Rod & Rod & Coccoid & & Coccoid & Coccoid & Rod & Rod & Coccoid \\
\hline Spore production & + & - & + & & + & + & + & + & + \\
\hline Motility & + & + & + & & + & + & - & - & + \\
\hline Pigmentation & Cream & Cream & Cream & & Cream & Cream & None & White & Cream \\
\hline Anaerobic growth & - & - & - & & - & - & - & - & - \\
\hline Gram stain & + & - & + & & + & + & + & + & + \\
\hline Optimal $\mathrm{NaCl}$ for growth (\%) & $7 \cdot 5$ & 10 & 10 & & 10 & 10 & 10 & 10 & 10 \\
\hline Optimal temperature for growth $\left({ }^{\circ} \mathrm{C}\right)$ & 30 & 37 & 37 & & 37 & 30 & 30 & 30 & 37 \\
\hline Optimal pH for growth & 7 & $6-7$ & $6-7$ & & $6-7$ & $6-7$ & $7 \cdot 5$ & $6-7$ & $6-7$ \\
\hline \multicolumn{10}{|l|}{ Sensitivity to antibiotics } \\
\hline Erythromycin & $S$ & $\mathrm{R}$ & $\mathrm{R}$ & & $\mathrm{R}$ & $\mathrm{R}$ & $S$ & S & $\mathrm{R}$ \\
\hline Bacitracin & $\mathrm{S}$ & $S$ & $\mathrm{~S}$ & & $\mathrm{R}$ & S & $\mathrm{R}$ & S & $\mathrm{S}$ \\
\hline Neomycin & $\mathrm{S}$ & $\mathrm{R}$ & S & & S & R & $\mathrm{R}$ & $\mathrm{R}$ & $\mathrm{R}$ \\
\hline Chloramphenicol & $S$ & $S$ & S & & S & S & $\mathrm{S}$ & $S$ & $\mathrm{~S}$ \\
\hline Ampicillin & $\mathrm{S}$ & $\mathrm{R}$ & S & & S & $\mathrm{R}$ & $\mathrm{R}$ & $\mathrm{R}$ & S \\
\hline Penicillin & $\mathrm{R}$ & $\mathrm{R}$ & S & & $S$ & $R$ & $\mathrm{R}$ & $\mathrm{S}$ & $S$ \\
\hline Rifampicin & $S$ & $\mathrm{R}$ & S & & S & S & $\mathrm{R}$ & S & $S$ \\
\hline
\end{tabular}


Table 1 (Continued)

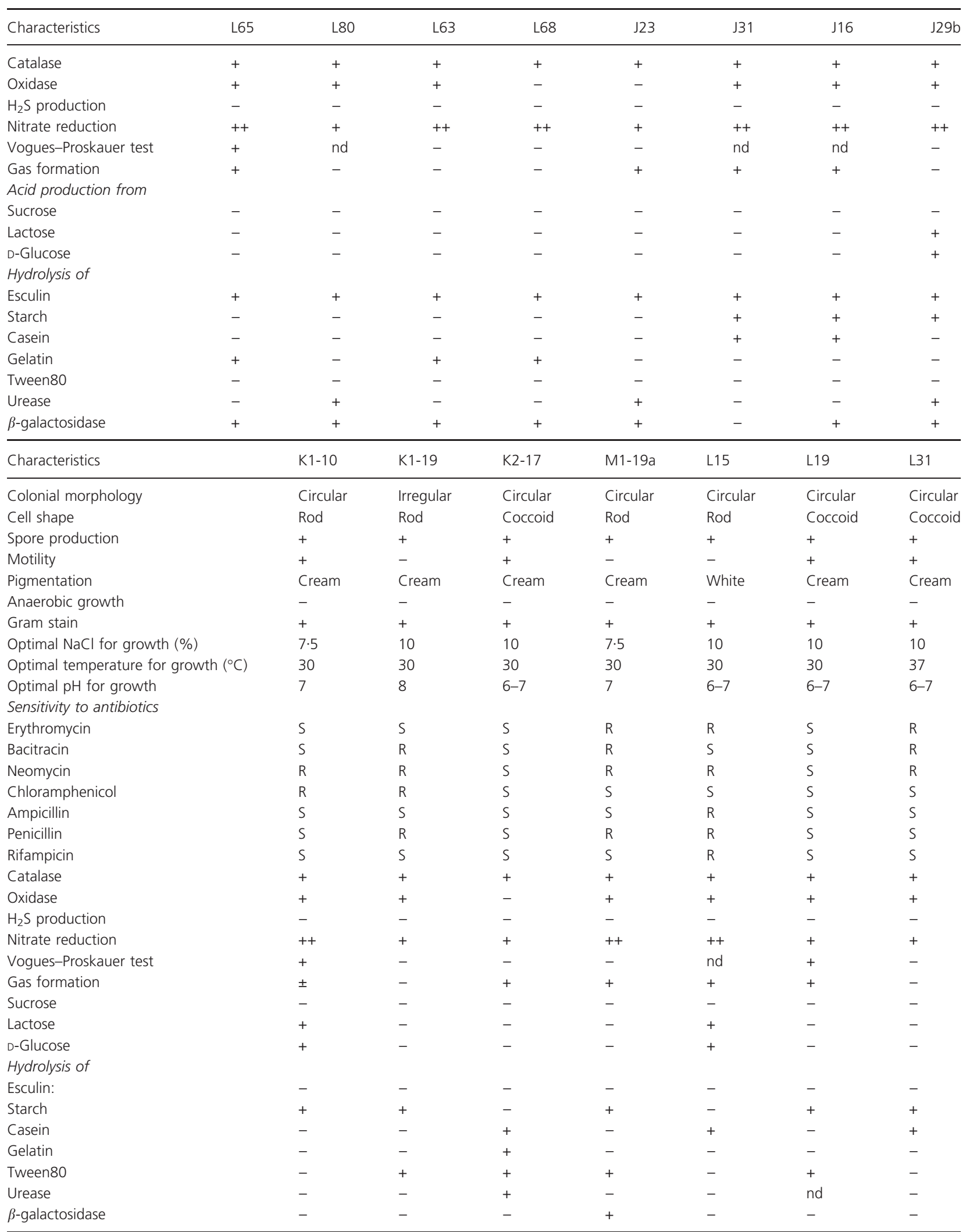

(+) Positive reaction; (-) negative reaction; (R) resistant to tested antibiotic; (S) sensitive to tested antibiotic; (++) reduction of nitrate to nitrite; $( \pm)$ unclear reaction; and (nd) not determined. 
Figure 2 Neighbour-joining tree based on 16S rDNA (1368 bases) sequences showing the phylogenetic relationship between strains K1-10, L65, M3-16, B1-33, J31, B1-21, L80 and other related species of Bacillus and Halomonas. Bootstrap values (expressed as percentages of 100 replications) greater than $70 \%$ are given at the nodes.

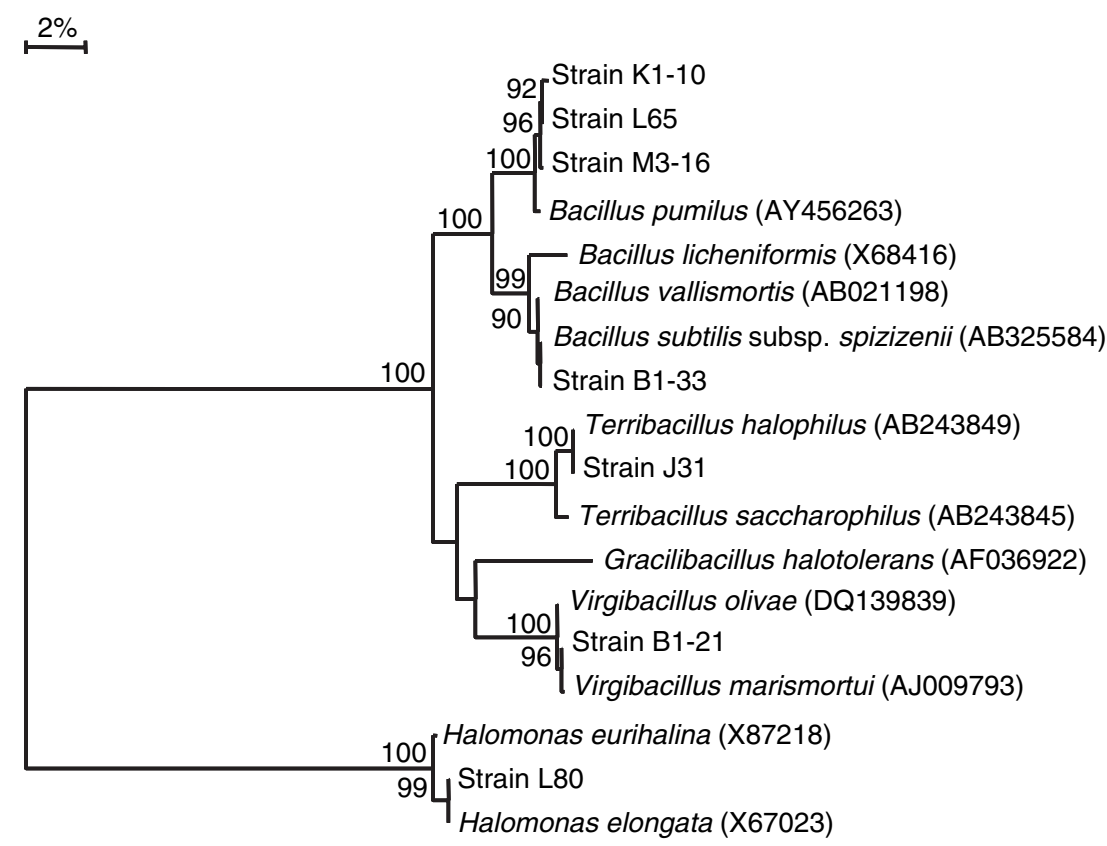

absence of the pathogen (Fig. 3). Chitinase production was significantly higher in medium (M2) containing glucose $\left(\mathrm{g}^{-1}\right)$ as a sole carbon source and the pathogen $\left(10^{6}\right.$ conidia $\left.\mathrm{ml}^{-1}\right)$. The chitinolytic activity in the latter medium ranged from $55 \cdot 21 \mathrm{U} \mathrm{ml}^{-1}$ for $\mathrm{M} 3-23$ to $295 \cdot 8 \mathrm{U} \mathrm{ml}^{-1}$ for M2-26. Lower chitinase amounts, were detected in media containing glucose (M1) or colloidal chitin (M4) as a sole carbon source (Fig. 3). In fact, the chitinolytic activities were not higher than $30 \cdot 19 \mathrm{U} \mathrm{ml}^{-1}$ and $67 \cdot 71 \mathrm{U} \mathrm{ml}^{-1}$ respectively in $\mathrm{M} 1$ and M4 media.

Finally, for media (M3) which contains glucose at $0 \cdot 1 \mathrm{~g} \mathrm{l}^{-1}$, chitinase activities ranged from $30.66 \mathrm{U} \mathrm{ml}^{-1}$ for M3-23 to $1.39 \mathrm{U} \mathrm{ml}^{-1}$ for J31. The results showed that chitinase activities were highly dependent with media composition (source of carbon) and presence or absence of the pathogen and the origin of the bacterial strain.

\section{Discussion}

Recent studies undertaken by Sadfi et al. (2001, 2002), showed the successful biocontrol of halotolerant bacteria in the inhibition of postharvest disease of potatoes induced by Fusarium sambucinum under storage conditions. Bacillus cereus and B. thuringiensis were found to reduce the disease incidence from $50 \%$ to $80 \%$ (Sadfi et al. 2002). Control of grey mould using halophilic antagonists has been successful for pre- and postharvest treatments of tomato crop in Tunisia (Sadfi-Zouaoui et al. 2007, 2008). The isolates halophilic strains from shallow salt lakes (Sadfi-Zouaoui et al. 2008) were tested on harvested strawberries for their effectiveness against B. cinerea. $20 \cdot 2 \%$ of the selected strains satisfactory controlled the pathogen. These bacteria are halotolerant to moderate halophiles, as they grew in media containing $0 \cdot 5-20 \% \mathrm{NaCl}(\mathrm{w} / \mathrm{v})$ (Ventosa et al. 1998). The moderate halophiles of Bacillus subtilis (M1-20, J9), B. licheniformis (J24), Staphylococcus equorum (L40, L50) and Planococcus rifietoensis (M2-26) had inhibited the mycelial growth of grey mould on wounded tomatoes (Sadfi-Zouaoui et al. 2008), and were active against the development of the disease on strawberries. Moreover, Virgibacillus marismortui, B. pumilus, Terribacillus halophilus, Halomonas elongata, Staphylococcus equorum and Staphylococcus sp., identified in this study by phenotypic tests and 16S rDNA sequencing, showed a good inhibitory effect against B. cinerea on harvested strawberry fruits. These bacteria produced extracellular hydrolytic antifungal enzymes, which may contribute to the suppression of grey mould rot on strawberry fruits.

Previous study showed the efficacy of hot water, biocontrol with Pichia guilliermondii yeast and controlled atmosphere in controlling grey mould on strawberries (Wszelaki and Mitcham 2000). Here, we first report on the inhibitory effects of moderately halophilic bacteria belonging to diverse genera of Planococcus, Virgibacillus, Terribacillus and Halomonas on the suppression of $B$. cinerea growth on strawberries. Their potential as biocontrol agents for grey mould is interesting and further investigation is needed to verify the effectiveness of these antagonists under long-term storage conditions and their ability to persist on strawberry plant for a long time. 
Table 2 Identity of the selected halophilic bacterial isolates, their range of tolerance to $\mathrm{NaCl}$, and their effect on the mycelial growth of B. cinerea in vitro

\begin{tabular}{|c|c|c|c|}
\hline $\begin{array}{l}\text { Growth range } \\
\text { at salt concentrations } \\
(\% \mathrm{NaCl})\end{array}$ & Strain & Identified as & ${ }^{\star} \mathrm{Gl}(\%)$ \\
\hline \multirow[t]{4}{*}{$5-10$} & J9 & Bacillus subtilis & $\mathrm{Oa}$ \\
\hline & B1-33 & Bacillus subtilis & $13 \cdot 82 b$ \\
\hline & $J 24$ & Bacillus licheniformis & $81 f$ \\
\hline & M1-20 & Bacillus subtilis & 94hi \\
\hline \multirow[t]{11}{*}{$5-15$} & B1-21 & Virgibacillus marismortui & $0 \mathrm{a}$ \\
\hline & K1-19 & Virgibacillus marismortui & Oa \\
\hline & M3-23 & Virgibacillus marismortui & $\mathrm{Oa}$ \\
\hline & K1-10 & Bacillus pumilus & $65 \cdot 05 d$ \\
\hline & M2-26 & Planococcus rifietoensis & $74 \cdot 5 e$ \\
\hline & M3-16 & Bacillus pumilus & $90 \cdot 5 \mathrm{gh}$ \\
\hline & M1-19a & Bacillus pumilus & $91 \cdot 5 \mathrm{gh}$ \\
\hline & M3-2 & Bacillus pumilus & 95hij \\
\hline & M3-6 & Bacillus pumilus & $98 \mathrm{ij}$ \\
\hline & L65 & Bacillus pumilus & $98 \cdot 5 \mathrm{ij}$ \\
\hline & L80 & Halomonas elongata & $99 \cdot 5 i$ \\
\hline \multirow[t]{16}{*}{$5-20$} & $\mathrm{~J} 16$ & Terribacillus halophilus & Oa \\
\hline & B1-35 & Staphylococcus equorum & Oa \\
\hline & L15 & Terribacillus halophilus & Oa \\
\hline & J31 & Terribacillus halophilus & Oa \\
\hline & 123 & Staphylococcus sp. & Oa \\
\hline & L63 & Staphylococcus equorum & $51 \cdot 35 c$ \\
\hline & L68 & Staphylococcus equorum & $79 \cdot 5 f$ \\
\hline & $J 29 b$ & Staphylococcus sp. & $88.80 \mathrm{~g}$ \\
\hline & $M 2-45$ & Staphylococcus sp. & $97 i j$ \\
\hline & L31 & Staphylococcus equorum & $97 \cdot 35 i j$ \\
\hline & L50 & Staphylococcus sp. & $97 \cdot 5 i j$ \\
\hline & K2-17 & Staphylococcus sp. & $97 \cdot 5 \mathrm{ij}$ \\
\hline & L19 & Staphylococcus sp. & $99 j$ \\
\hline & L40 & Staphylococcus sp. & $99 j$ \\
\hline & B1-28 & Staphylococcus sp. & $99 j$ \\
\hline & Control & & $\mathrm{Oa}$ \\
\hline
\end{tabular}

*Growth inhibition $(\mathrm{Gl})=\left(R_{1}-R_{2}\right) / R_{1} \times 100$, where $R_{1}$ represents the distance (measured in millimeter) between the point of implant of the fungal disk and the side of the Petri plate, and $R_{2}$ is the distance of fungal growth from the point of inoculation to the colony margin in the direction of the antagonist (Sadfi-Zouaoui et al. 2008). Halotolerant to moderately halophilic strains were identified by phenotypic tests and $16 \mathrm{~S}$ rDNA sequencing.

Means followed by a common letter are not significantly $(P=0.05)$ different according to LSD test.

In controlling fungal plant pathogens, a variety of mechanisms contribute to the biocontrol activity of microbes (Kim and Kim 1994). Cell-wall-degrading enzymes such as $\beta$-1,3-glucanases, cellulases, proteases and chitinases are involved in the antagonistic activity of some biological control agents against phytopathogenic fungi (Chérif et al. 1992). The antifungal enzymes from halophilic bacteria have not been investigated (SadfiZouaoui et al. 2008). Suppression of B. cinerea growth
Table 3 Effects of volatiles of halophilic bacteria on radial growth of B. cinerea

\begin{tabular}{ll}
\hline Treatment & $\begin{array}{l}\text { Mean radial growth of } \\
\text { fungal colony }(\mathrm{mm})\end{array}$ \\
\hline Control & $64 \cdot 83 \pm 4 \cdot 53 \mathrm{~d}$ \\
J31 & $62 \cdot 33 \pm 2 \cdot 51 \mathrm{~d}$ \\
J9 & $52 \cdot 50 \pm 3 \cdot 77 \mathrm{~cd}$ \\
M2-26 & $39 \cdot 17 \pm 3 \cdot 54 \mathrm{bc}$ \\
J24 & $27 \cdot 17 \pm 5 \cdot 53 \mathrm{ab}$ \\
L80 & $33 \cdot 00 \pm 3 \cdot 90 \mathrm{~b}$ \\
M3-23 & $26 \cdot 67 \pm 12 \mathrm{ab}$ \\
M3-16 & $9 \cdot 50 \pm 1 \cdot 32 \mathrm{a}$ \\
\hline
\end{tabular}

Data are the average of three replications \pm the standard error of the means. Means followed by a common letter are not significantly $(P=0.05)$ different according to LSD test.

in vitro by the selected moderately halophilic isolates and formation of inhibition zones were presumably due to the metabolites being released from bacteria into the culture medium. Although ineffective in vitro on PDA medium, V. marismortui (B1-21, M3-23, K1-19) and Terribacillus halophilus (J16, J31) isolates effectively inhibited grey mould on strawberry fruits. This confirms the idea that bacterial isolates unable to form inhibition zones on solid medium are not necessarily incapable of inhibiting disease development in vivo. These isolates may assume their antagonistic effect by mainly producing cell-bound antifungal compounds (Edwards 1993; Walker et al. 1998) or

Table 4 Extracellular hydrolytic activity of antifungal halophilic strains

\begin{tabular}{lllll}
\hline & \multicolumn{3}{l}{ Characteristics } & \\
\cline { 2 - 5 } & & & & $\beta-1$, \\
Strains & Cellulase & Protease & Chitinase & 3 -glucanase \\
\hline Terribacillus & - & - & + & + \\
halophilus L15 & & & & \\
Terribacillus & - & + & + & + \\
halophilus J31 & & & & \\
Terribacillus & - & + & + & + \\
halophilus J16 & & & & \\
B. subtilis B1-33 & + & + & + & + \\
B. pumilus M3-16 & + & + & + & + \\
B. pumilus M3-2 & + & - & + & + \\
B. pumilus K1-10 & - & - & + & + \\
B. pumilus L65 & - & - & + & + \\
B. pumilus M3-6 & - & - & + & + \\
B. pumilus M1-19a & - & - & + & + \\
B. marismortui M3-23 & - & - & + & + \\
B. marismortui B1-21 & - & - & + & + \\
B. marismortui K1-19 & - & - & + & + \\
Halomonas elongata L80 & - & - & ND & +
\end{tabular}

Symbols: (+) strain produces the enzymes; (-) strain does not produce the enzyme; ND - none detected. 
Figure 3 Effect of different growth media on chitinase activity in T. halophilus J31, V. marismortui $\mathrm{M} 3-23$, B. subtilis $\mathrm{J9}$, B. pumilus M3-16, B. licheniformis $\mathrm{J} 24$, and $P$. rifitioensis $\mathrm{M} 2-26$. For each strain, differentially shaded bars represent (from left to right) chitinase production in M1, M2, M3 and M4 media (also see Materials and methods) after 5 days of incubation at $37^{\circ} \mathrm{C}$. Chitinase activity is expressed in units per $\mathrm{ml}$ of cell-free supernatant. Bars with the same letter did not differ significantly at $P=0.05$ by LSD test.

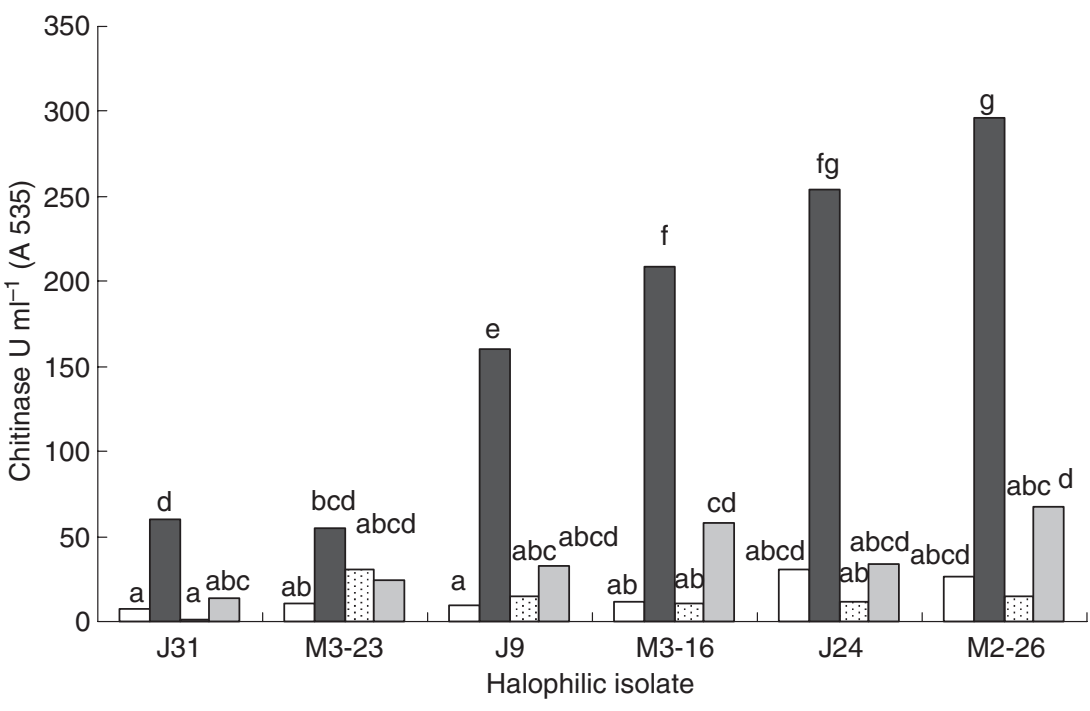

indirectly by inducing plant resistance mechanisms and/or by nutrient competition (Kehlenbeck et al. 1994; Muninbazi and Bullerman 1998).

This study has shown the production of antifungal enzymes from the halophilic isolates as all isolates possess chitinase and glucanase activities. The chitinase production was highly induced by the presence of autoclaved spores of $B$. cinerea in vitro and it was dependent on the presence of glucose or colloidal-chitin as a sole carbon source in the growth medium. This suggests that medium composition (glucose content) affected induction of chitinase enzyme. These data correlate with results of Nielsen and Sorensen (1997), who suggested the influence of medium composition (glucose content) on the cell wall degrading enzymes produced by B. pumilus strains. Furthermore, Leelasuphakul et al. (2006) demonstrated that $\beta$-1,3-glucanase produced by $B$. subtilis was induced by the addition of chitin into the growth medium. Although, the number of reports dealing with microbial chitinases is increasing, the mechanisms of degradation and utilization of the insoluble chitin substrate by micro-organisms, including the induction mechanisms remain still unclear (Watanabe et al. 1990).

In this study, B. subtilis, B. licheniformis, B. pumilus and $V$. marismortui were shown to secrete chitinolytic enzymes thus supporting earlier reports of chitinase production in several potential biocontrol Bacillus species, including B. circulans (Watanabe et al. 1990), B. licheniformis (Trachuck et al. 1996), B. cereus (Pleban et al. 1997) and B. thuringiensis (Chigaleichik 1976). Evidence that these chitinolytic enzymes play a major role in the biocontrol of fungal pathogens has been demonstrated in many systems involving bacterial and fungal antagonists (Lorito et al. 1994). However, to our knowledge, no data about quantitative chitinase production from Planococcus rifietoensis has been published. It was interesting to note very high amounts of chitinases $\left(295.8 \mathrm{U} \mathrm{ml}^{-1}\right)$ produced by this moderately halophilic species determined by the release of reducing sugars from colloidal chitin. This study further confirms the potential of halophilic bacteria to produce important hydrolytic enzymes.

In this study, some Bacillus species were found to produce volatile compounds on PDA plates. Whether, these antifungal volatiles contribute to grey mould suppression on strawberries remains to be demonstrated. Nevertheless several studies revealed the importance of antifungal volatiles in the biocontrol of different plant diseases (Dennis and Webster 1971). The effect of volatile compounds has received only limited attention in comparison to the antagonism because of diffusible substances (Chaurasia et al. 2004). Only two halotolerant strains of $B$. pumilus and B. licheniformis developed antibiotic activity on solid medium, while the rest of isolates were unable to inhibit the growth of $B$. cinerea by the cellfiltrates. Similarly to works of Sadfi et al. (2001), the ineffectiveness of culture supernatants of halotolerant Bacillus isolates may merely indicates that the antifungal compounds were not produced in the culture media in the absence of the pathogen or were produced at low concentrations insufficient to inhibit the pathogen. Several hydrolytic enzymes are produced by Bacillus species especially $\beta$-1, 3-glucanase and protease which play a role in the decomposition of fungal cell-walls (Lim et al. 1991) and may be important determinants in the antagonistic process (Chérif and Benhamou 1990).

Bacillus and Staphylococcus were the most abundant species in the collection established from different hypersaline ecosystems in Tunisia. These results are in 
agreement with works of Hacene et al. (2003) and SadfiZouaoui et al. (2008). Staphylococcus spp. are potential pathogens for human and animals and must be omitted in our biocontrol screening because of their serious public health risk.

This study demonstrates that moderate halophiles suppressed or at least reduced the grey mould disease caused by $B$. cinerea on strawberry fruits under commercial standard conditions. The use of such bacteria may constitute an important alternative to synthetic fungicides and may be useful for disease management programmes. The biological control potential of halophilic bacteria may be correlated with their ability to produce several extracellular antifungal hydrolytic enzymes (chitinase, $\beta$-1, 3-glucanase, cellulase and protease). Current studies are undertaken to correlate between the concentration of salt in the medium and the production of bioactive compounds (enzymes and antibiotics). Our results showed that for majority of tested strains cultivation under optimal salt concentration yielded highest level of hydrolytic activities (B. Essghaier, H. Jijakli, A. Bondabons, N. Sadfi-Zouaoui and M. Bejji, unpublished data), which is in agreement with results of $\mathrm{Xu}$ et al. (2003).

Moreover, Greenway and Osmond (1972) have proved that enzymes from halophilic bacteria require high salt concentration during assay for optimal activity. Further studies are currently in progress to select the best producers of hydrolytic enzymes from the novel effective isolates and investigations should be directed towards the characterization and purification of the corresponding encoding genes. In addition to test the efficiency of the antagonistic bacteria in reducing disease on strawberry plant under greenhouse and field conditions.

\section{Acknowledgements}

This work was supported by funds from CMCU (Comite Mixte de Coopération Franco-Tunisien no 06S/0901), and by the Ministry of Scientific Research and Competency Development (MRSDTC, Tunisia) 206, 207.

\section{References}

Barritt, M.M. (1936) The intensification of the Voges-Proskauer reaction by the addition of $\alpha$-naphtol. J Pathol Bacteriol 42, 441-445.

Benson, D., Boguski, M.S., Lipman, D.J., Ostell, J., Ouellette, B.F., Rapp, B.A. and Wheeler, D.L. (1999) GenBank. Nucleic Acids Res 27, 12-17.

Bull, C.T., Stack, J.P. and Smilanick, J.L. (1997) Pseudomonas syringae strains ESC-10 and ESC-11 survive in wounds on Citrus and control green and blue molds of citrus. Biol Control 8, 81-88.
Burmeister, D.M., Ball, S., Green, S. and Woolf, A.B. (1997) Interaction of hot water treatments and controlled atmosphere storage on quality of 'Fuyu' persimmons. Postharvest Biol Technol 12, 71-81.

Chaurasia, B., Pandey, A., Palni, L., Man., S., Trivedi, P., Kumar, B. and Colvin, N. (2004) Diffusible and volatile compounds produced by an antagonistic Bacillus subtilis strain cause structural deformations in pathogenic fungi in vitro. Microbiol Res 160, 75-81.

Chérif, M. and Benhamou, N. (1990) Cytochemical aspects of chitin breakdown during the parasitic action of a Trichoderma sp. on Fusarium oxysporum f. sp. radicis lycopersici. Phytopathology 80, 1406-1414.

Chérif, M., Benhamou, N. and Bélanger, R.R. (1992) Occurrence of cellulose and chitin in the hyphal cell walls of Pythium ultimum: a comparative study with other plant pathogenic fungi. Can J Microbiol 39, 213-222.

Chigaleichik, A.G. (1976) Chitinase of Bacillus thuringiensis. Mikrobiologiya 45, 966-972.

Christensen, W.B. (1946) Urea decomposition as a means of differentiating Proteus and paracolon cultures from each other and from Salmonella and Shigella. J Bacteriol 5, 461-466.

Clarke, P.H. (1953) Hydrogen sulphide production by bacteria. J Gen Microbiol 8, 397-407.

Dennis, C. and Webster, J. (1971) Antagonistic properties of species-group of Trichoderma II. Production of volatile antibiotics. J Agric Food Chem 20, 437-438.

Edwards, S.G. (1993)Biological control of Botrytis cinerea by Bacillus brevis on protected Chinese cabbage. $\mathrm{PhD}$ thesis, University of Aberdeen, Aberdeen, UK.

El-Ghaouth, A., Charles, L.W. and Wisniewski, M. (1998) Ultrastructural and cytochemical aspects of the biological control of Botrytis cinera by Candidate sanitoana in apple fruit. Phytopathology 88, 282-291.

Fiddman, P.J. and Rossall, S. (1995) Selection of bacterial antagonists for the biological control of Rhizocotonia solani in oilseed rape (Brassica napus). Plant Pathol 44, 695-703.

Gomez Ramirez, M., Rojas Avelizapa, L.I., Rojas Avelizapa, N.G. and Cruz Camarillo, R. (2003) Colloidal chitin stained with Remazol Brillant Blue $\mathrm{R}^{\circledR}$, a useful substrate to select chitinolytic microorganisms and to evaluate chitinases. J Microbiol Methods 56, 213-219.

Grant, W.D., Kamekura, M., Genity, Mc. and Ventosa, A. (2001) Family 1. In Bergey's Manual of Systematic Bacteriology eds Boone, D.R., Castenholz, R.W. and Garrity, G.M. pp. 299-339. 2nd edn, Vol. 1. New York: Springer.

Greenway, H. and Osmond, C.B. (1972) Salt responses of enzymes from species differing in salt tolerance. Plant Physiol 49, 256-259.

Hacene, H., Rafa, F., Chebhoyni, N., Bouthiba, S., Bhatnagar, T., Baratti, C.J. and Ollivier, B. (2003) Biodiversity of prokaryotic microflora in El Golea Salt lake Algerian Sahara. J Arid Environ 58, 273-284. 
Hall, T.A. (1999) BioEdit: a user-friendly biological sequence alignment editor and analysis program for Windows 95/98/NT. Nucleic Acids Symp Ser 41, 95-98.

Ippolito, A., Schena, L., Pentimone, I. and Nigro, F. (2005) Control of postharvest rots of sweet cherries by pre-and postharvest applications of Aureobasidium pullulans in combination with calcium chloride or sodium bicarbonate. Postharvest Biol Technol 36, 245-252.

Kehlenbeck, H., Krone, C., Oerke, E.C. and Schönbeck, F. (1994) the effectiveness of induced resistance on yield of mildewed barley. J Plant Dis Prot 101, 11-21.

Kim, Y.S. and Kim, S.D. (1994) Antifungal mechanism and properties of antibiotic substance produced by Bacillus subtilis YB-70 as a biological control agent. J Microbiol Biotechnol 4, 296-304.

Leelasuphakul, W., Sivanunsakul, P. and Phongpaichit, S. (2006) Purification, characterization and synergetic activity of $\beta$-1, 3-glucanase and antibiotic extract from an antagonistic Bacillus subtilis NRS 89-24 against rice blast and sheath blight. Enzyme Microb Technol 38, 990-997.

Lim, H.S., Kim, Y.S. and Kim, S.D. (1991) Pseudomonas stutzeri YPL-1 genetic transformation and antifungal mechanism against Fusarium solani, an agent of root rot. Appl Environ Microbiol 57, 510-516.

Lorito, M., Hayes, C.K., Di Pietro, A., Woo, S.L. and Harman, G.E. (1994) Purification, characterization, and synergistic activity of a glucan-1-3- $\beta$-glucosidase and an N-acetyl$\beta$-glucosaminidase from Trichoderma harzianum. Phytopathology 84, 398-405.

Lowe, G.H. (1962) the rapid detection of lactose fermentation in paracolon organisms by the demonstration of $\beta$-Dgalactosidase. J Med Lab Technol 19, 21.

Maidak, B.L., Cole, J.R., Lilburn, T.G., Parker, C.T., Saxman, P.R., Farris, R.J., Garrity, G.M., Olsen, G.J. et al. (2001) The RDP-II (Ribosomal Database project). Nucleic Acids Res 29, 173-174.

Muninbazi, C. and Bullerman, L.B. (1998) Isolation and partial characterization of antifungal metabolites of Bacillus pumilus. J Appl Microbiol 84, 959-968.

Niehaus, F., Bertoldo, C., Kahler, M. and Antranikian, G. (1999) Extremophiles as a source of novel enzymes for industrial application. Appl Microbiol Biotechnol 51, 711-729.

Nielsen, P. and Sorensen, J. (1997) Multi-target and medium-independent fungal antagonism by hydrolytic enzymes in Paenibacillus polymyxa and Bacillus pumilus strains from barley rhizosphere. FEMS Microbiol Ecol 22, 183-192.

Ordentlich, A., Elad, Y. and Chet, I. (1988) The role of chitinase of Serratia marcescens in biocontrol of Sclerotium rolfsii. Phytopathology 78, 84-88.

Paulus, A.O. (1990) Fungal diseases of strawberry. Hort Sci 25, 885-889.

Peng, G. and Sutton, J.C. (1991) Evaluation of microorganisms for biocontrol of Botrytis cinerea in strawberry. Can J Plant Pathol 13, 247-257.
Pleban, S., Chernin, L. and Shet, I. (1997) Chitinolytic activity of endophytic strain of Bacillus cereus. Lett Appl Microbiol 25, 284-288.

Rodriguez-Kabana, R., Godoy, G., Morgan-Jones, G. and Shelby, R.A. (1983) the determination of soil chitinase activity: conditions for assay and ecological studies. Plant Soil 75, 95-106.

Roja Avelizapa, L.I., Cruz Camarillo, R., Guerro, M.I., Rodriguez Vazquez, R. and Ibarra, J.E. (1999) Selection and characterization of a proteo-chitinolytic strain of Bacillus thuringiensis, able to grow in shrimp waste media. World J Microbiol Biotechnol 15, 299-308.

Sadfi, N., Cherif, M., Fliss, A., Boudabous, A. and Antoun, H. (2001) Evaluation of bacterial isolates from salty soils and Bacillus thuringiensis strains for the biocontrol of Fusarium Dry rot of Potato tubers. J Plant Pathol 83, 101-118.

Sadfi, N., Cherif, M., Hajlaoui, M.R. and Boudabous, A. (2002) Biological control of the potato tubers dry rot caused by Fusarium roseum var. sambucinum under greenhouse, field and storage conditions using Bacillus spp. isolates. J Phytopathol 150, 640-648.

Sadfi-Zouaoui, N., Essghaier, B., Hannachi, I., Hajlaoui, M.R. and Boudabous, A. (2007) First report on the use of moderately halophilic bacteria against stem canker of greenhouse tomatoes caused by Botrytis cinerea. Ann Microbiol 57, 337339.

Sadfi-Zouaoui, N., Essghaier, B., Hajlaoui, M.R., Fardeau, M.L., Cayol, J.L., Ollivier, B. and Boudabous, A. (2008) Ability of moderately halophilic bacteria to control Grey mould disease on tomato fruits. J Phytopathol 156, 42-52.

Saligkarias, I.D., Gravanis, F.T. and Epton, A.S. (2002) Biological control of Botrytis cinerea on tomato plants by the use of epiphytic yeasts Candida guilliermondii strains 101 and US 7 and Candida oleophila strain I-182: II. A study on mode of action. Biol Control 25, 151-161.

Schestibratov, K.A. and Dolgov, S.V. (2005) Transgenic strawberry plants expressing a thaumatin II gene demonstrate enhanced resistance to Botrytis cinerea. Sci Hortic 106, 177-189.

Schouten, R.E., Kessler, D., Orcaray, L. and Kooten, O.V. (2002) Predictability of keeping quality of strawberry batches. Postharvest Biol Technol 26, 35-47.

Skerman, V.B.D. (1967). A Guide to the Identification of the Genera of Bacteria, 1st edn. Baltimore, MD: Williams and Wilkins Co.

Sutton, J.C. (1990) Epidemiology and management of Botrytis leaf blight of anion and grey mould of strawberry: a comparative analysis. Can J Plant Pathol 12, 100-110.

Sutton, J.C. and Peng, G. (1993) Biocontrol of Botrytis cinerea in strawberry leaves. Phytopathology 83, 615-621.

Tindall, B.J. (1992) The Family Halobacteriaceae. In The Prokaryotes. A Handbook of Bacteria: Ecophysiology, Isolation, Identification, Application eds. Balows, A., Trüper, H.G., Harder, W. and Schleifer, K.H. pp. 768-808. 2nd edn, Vol.1. New York: Springer. 
Trachuck, L.A., Revina, L.P., Shemyakina, T.M., Chestukhina, G.G. and Stepanov, V.M. (1996) Chitinases of Bacillus licheniformis B6839: isolation and properties. Can J Microbiol 42, 307-315.

Utkhede, R.S., Bogdanoff, C. and McNevin, J. (2001) Effects of biological and chemical treatments on Botrytis stem canker and fruit yield of tomato under greenhouse conditions. Can J Plant Pathol 23, 253-259.

Van de Peer, Y. and De Wachter, R. (1994) TREECON for Windows: a software package for the construction and drawing of evolutionary trees for the Microsoft Windows environment. Comput Appl Biosci 10, 569-570.

Ventosa, A., Nieto, J.J. and Oren, A. (1998) Biology of moderately halophilic aerobic bacteria. Microbiol Mol Biol Rev 62, 504-544.

Walker, R., Powel, A.A. and Seddon, B. (1998) Bacillus isolates from the spermosphere of peas and dwarf French beans with antifungal activity against Botrytis cinerea and Pythium species. J Appl Microbiol 84, 791-801.
Watanabe, T., Oyanagi, W., Suzuki, K. and Tanaka, H. (1990) Chitinase system Bacillus circulans WL-12 and importance of chitinase A1 in chitin degradation. J Bacteriol 172, 4017-4022.

Wilson, M.E. and Wisniewski, C.J. (1989) Biological control of postharvest diseases of fruits and vegetables; an emerging technology. Ann Rev Phytopathol 27, 425-441.

Winker, S. and Woese, C.R. (1991) A definition of the domains Archae, Bacteria and Eucarya in terms of small subunit ribosomal RNA characteristics. Syst Appl Microbiol 13, 161-165.

Wszelaki, A. and Mitcham, E.J. (2000) Effects of superatmospheric oxygen on strawberry fruit quality and decay. Postharvest Biol Technol 20, 125-133.

Xu, Y., Feller, G., Gerday, C. and Glandorff, N. (2003) Metabolic enzymes from psychrophilic bacteria: challenge of adaptation to low temperatures in ornithine carbamoyltransferase from Morytellaabyssi. J Bacteriol 185, 21612168. 